\title{
The Visibility of Hygiene Self-Care in Nurse-to-Nurse Shift Change Reports
}

\author{
Maria Helena de Oliveira Penaforte ${ }^{1}$ \\ Maria Manuela Ferreira Pereira da Silva Martins²
}

This study aimed to understand the visibility of hygiene care related to inpatients with compromised self-care through the nurse-to-nurse shift change report. A qualitative approach was used and data were collected through observation and semi-structured interviews. A total of 33 nurses from medical and surgical units were observed and eight of them were interviewed. The results indicate that the nurse-to-nurse shift change report is a cyclically recreated practice that results in group coherence in updating information and in the continuity of care, and keeps nurses united. Hygiene care activities are present in the shift change reports; they are frequent in the shift change from morning to afternoon and less frequent in the remaining. Information concerning these activities helps to determine the type of aid necessary to the continuity of hygiene and of many other care activities and the rhythm of the following shifts.

Descriptors: Nursing Research; Self Care; Shift Work.

\footnotetext{
${ }^{1}$ RN, Doctoral Student in Nursing, Universidade de Lisboa, Portugal. Centro Hospitalar de Trás-os-Montes e Alto Douro, Portugal E-mail: mariaop@chtmad.min-saude.pt.

${ }^{2}$ Ph.D. in Nursing Sciences, Professor Coordinator, Escola Superior de Enfermagem do Porto, Portugal. E-mail: mmartins@esenf.pt.
}

Corresponding Author:

Maria Manuela Ferreira Pereira da Silva Martins

Escola Superior de Enfermagem do Porto (ESEP)

Rua Dr. António Bernardino de Almeida

CEP: $4200-072$ Porto, Portugal

E-mail: mmartins@esenf.pt 


\section{A visibilidade do autocuidado relativo à higiene na passagem de plantão dos enfermeiros}

Objetivou-se compreender a visibilidade dos cuidados de higiene na informação da passagem de plantão, inerentes à pessoa internada com o autocuidado comprometido. Recorreu-se à abordagem qualitativa, utilizando-se a observação e a entrevista semiestruturada. Foram observados 33 enfermeiros, 8 dos quais foram entrevistados, provenientes de um serviço de medicina e outro de cirurgia. Dos achados, pode-se salientar que a passagem de plantão é prática recriada ciclicamente e aponta para o sentido de coerência do grupo na reatualização da informação, na continuidade dos cuidados e mantém unidos os enfermeiros. Os cuidados de higiene marcam presença nos relatos da passagem de plantão, com vínculo explícito na do turno das 14h30min e implícito nas restantes passagens. A informação sobre esses proporciona orientações para determinar o tipo de ajuda à sua continuação e a muitos outros cuidados, atividades e ritmo do turno seguinte.

Descritores: Pesquisa em Enfermagem; Autocuidado; Trabalho em Turnos.

\section{La visibilidad del autocuidado higiene en el cambio de turno de los enfermeros}

El objetivo fue comprender la visibilidad de los cuidados de higiene en la información del cambio de turno, inherentes a la persona internada con el autocuidado comprometido. Se recurrió al abordaje cualitativo, utilizando la observación y la entrevista semiestructurada. Fueron observados 33 enfermeros, 8 de los cuales fueron entrevistados, provenientes de un servicio de medicina y otro de cirugía. De los hallazgos, se puede destacar que el cambio de turno es una práctica recreada cíclicamente y apunta para el sentido de coherencia del grupo en la reactualización de la información, la continuidad de los cuidados y mantiene unidos a los enfermeros. Los cuidados de higiene muestran su presencia en los relatos del cambio de turno, con vínculo explícito en el turno de las 14 h30min e implícito en los restantes cambios. La información sobre estos proporciona orientaciones para la continuación de dichos cuidados, así como de los restantes cuidados, actividades y ritmo del próximo turno.

Descriptores: Investigación en Enfermaría; Autocuidado; Trabajo por Turnos.

\section{Introduction}

The nurse-to-nurse shift change report is a practice used by nurses to ensure the continuity of care delivery ${ }^{(1)}$. It has been described in the literature as a space in which information is verbally transmitted: how health care in general was and should be delivered, especially personalized and continued nursing care, when the patient is socially and generally privileged(2). It is a point when nurses end their work journey, update their colleagues in relation to actions performed and provide guidance concerning the next ones(3). Management of information is highly relevant at this point because it gives visibility to the effective individual and collective management of information necessary to nursing care ${ }^{(3)}$. It is acknowledged as a practice that uses communication as a basic tool of nursing, which favors the exchange of information and is a communication exercise within the nursing team ${ }^{(4)}$.

From the perspective of sustained development, the need for nurses to show communication skills within the group is reported as a way to practice humanizing processes with patients when they communicate according to current models(2). There is a convergent 
aspect in various studies ${ }^{(2-5)}$ related to the nurse-to-nurse shift change report from the perspective of development as an amount of time used, not only to transmit clinical information concerning patients but also different perspectives may be assumed when new situations are learned(5). This practice allows nurses to acquire a different view, analyze, discuss and create nursing practice, which is an essential condition for nurses to develop their skills in care delivery ${ }^{(2,5)}$. Communication is therefore a skill essential to nursing professionals who should pay attention to informative content and the results of the communicative process ${ }^{(1)}$.

Consequently, the deontological code of nurses in Portugal reinforces that nurses should "under all circumstances, keep in the performance of their activities, a personal standard of conduct that dignifies the profession"(6). It is also the role of nurses "...to ensure the continuity of care, faithfully recording observations and interventions performed"(6), which reinforces what is recommended in different nursing models, consolidating the need to promote the care process and ensure the continuity of care.

This study provides evidence that the communication used in the nurse-to-nurse shift change report emerges as: a way to ensure the continuity of nursing care ${ }^{(1-6)}$, administrative communication given care and the nursing care process ${ }^{(1-4)}$; communication of data records ${ }^{(4)}$; and the development of skills and competencies ${ }^{(1-6)}$.

Specifically considering the self-care theory ${ }^{(7)}$ that supports this concept as the practice of activities that individuals initiate and perform to their own benefit to maintain life, health and wellbeing(7), also implies that the requirement of self-care, when formulated and expressed, constitutes the goals of formalized self-care. These are the reasons self-care is practiced, acknowledging that one of the nursing care goals should be to encourage the active participation of patients in their own treatment, sharing with the nurse the responsibility to implement care and its results ${ }^{(8)}$.

Hence, it is the role of nurses to act, selecting help methods and focusing their actions according to the requirements of self-care to enable patients to progress and become autonomous ${ }^{(7,9)}$.

The literature addressing self-care reveals that hygiene care practices pervade various universal selfcare activities that are differently developed throughout life and that is why these are linked to the development of self-care and can become a way to assist poor selfcare when there is a health problem(7).

The need to act out, think on and address self-care has been a concern of nurses around the world, hence it is categorized as a type of action performed by the patient him/herself(10).

A study comparing the nursing process among units showed the existence of nursing records in the patients' medical files but not of nursing diagnoses. It also showed that the systematization of nursing care is present in the team's daily activities. The differences between theoretical and practical information, which harm the implementation of the nursing process, are indicated $^{(11)}$. The need to seek strategies to minimize this gap is highlighted in order to implement the continuous development of the work process, taking the challenge of a critical and reflexive paradigm(12), in which, even in the face of limitations in the communicative process, nurses show possibilities for changes emphasizing professional education and qualification ${ }^{(13)}$. It implies that professionals should have an interest and responsibility in the face of routine situations as reinforced in a study addressing the preparedness of nurses to deliver care ${ }^{(14)}$. Preparing the environment is not merely preparing the physical area but it is also related to the care the health unit and workers have to deliver, where the posture of workers and the use of resources available to adapt responses to the needs of patients are present ${ }^{(14)}$. It is worth noting that there is a need to look at the nurse-tonurse shift change report as verbal information through which nurses report the inpatients' self-care given its role as mechanism to ensure the continuity of care ${ }^{(1)}$, as a moment of permanent training in the context of work, and also an opportunity to prepare the care environment, the nurse him/herself and care delivery, to meet the patients' needs ${ }^{(14)}$.

The perception of those under study helps one to grasp the relevance and power of communication in the nurse-to-nurse shift change report, giving form to our concerns focused on the communication inherent to the hygiene self-care in this practice.

Given the preceding discussion, we believe the study of this subject can contribute to: reflecting on the current practice of the nurse-to-nurse shift change report considering the integrality that permeates selfcare; developing communication abilities and skills in the nurse-to-nurse shift change report given the relevance of assisting self-care, more specifically hygiene care and continuity of care; warn students, nurses and team leaders of the need to transmit information during the nurse shift change report based on nursing care in order to improve it. Therefore, the objectives of this study include understanding the visibility of self-care hygiene in information provided in the nurse-to-nurse shift change reports. 


\section{Material and methods}

This is a qualitative, descriptive, exploratory and analytical study. The methods used to collect data were observation and interviews. The study was carried out in two hospitalization services of a hospital in the north of Portugal: one medical and one surgical unit. The structure of the nurses' daily work in both services encompasses three shifts that cover a 24-hour period: morning ( $8: 30 \mathrm{am}$ to $3: 30 \mathrm{pm}$ ), afternoon (3pm to $10 \mathrm{pm}$ ) and night (10pm to $8: 30 \mathrm{am})$. The transition between each shift is marked by the shift change report where nurses talk about what happened to patients under their responsibility after making formal records. The method of work was individual.

The organization of human resources followed the development of a set of a large number of activities in the morning shift, among which are nursing care activities that include the patients' hygiene and bathing.

A total of 33 nurses from the two services were observed: 17 from the medical service and 16 from the surgical service. The following inclusion criteria were followed: being a member of the nursing team of one of the services; being present during the nurseto-nurse shift change reports; having patients under their responsibility; not being in training; and providing consent to participate in the study.

The interviews were carried out with eight of the 33 observed nurses (four per service). The inclusion criteria for the participants to be interviewed were: working in the morning shift; delivering daily nursing care that included the patients' hygiene and/or bath; being responsible for training new co-workers; being a specialist nurse or attending a nursing specialization program; and having at least three years of experience in the current service. The group of interviewees has special knowledge concerning the topic of study such as the existing hospitalization processes, cultural rules, rituals and language used. Therefore, the researcher can turn to these professionals to validate her ideas or perceptions of what was observed ${ }^{(16)}$.

All the deontological assumptions inherent to research ethics and recommended by the Helsinki declaration were followed during the methodological process. The Hospital directors and Research Ethics Committee authorized the study and the nurses who worked in the hospitalization services consented to participate in the study through free and informed consent forms and were also ensured of their confidentiality.

Data collection was carried out between December 2007 and June 2008 in the two services. Direct and systematized observation first targeted the characteristics of the nurse-to-nurse shift change report, characteristics of information transmitted and its management. Each service was visited once a week and different nurseto-nurse shift change reports were observed, totaling 42 observation records (21 per service). Observation focused on the situation in which information concerning each patient was transmitted by nurses during the shift change reports. Observations were immediately recorded in a proper form. This form was divided into two parts: the left side was reserved for the researcher's records/comments and the right side for analysis. The participants' dialogs were included in the form.

The observation process enabled the researcher to become familiar with the participants and the context from which information that needed to be clarified and understood emerged and guided the semi-structured interviews. The interviews were carried out to obtain the participants' representations and learn what information was provided and used, how they used it and its effects. The following questions were asked to all interviewees: What does the shift change report represent to you? What information do you usually transmit? How does the person who receives it use it? What is the hierarchy of information? What is the meaning of 'hygiene care' in this information? The interviews were recorded with the participants' consent and then transcribed by the researcher.

The analysis and interpretation of data were based on the proposal of analysis(17), which is focused on the analysis of domains and taxonomic, componential and thematic analysis. The records of the observations and interviews were used to identify the cultural domains. The records were carefully read and re-read to understand their content. After exploring the records, units of data with meaning for this context were extracted from them (expressions and phrases). Some categories were identified and the included terms were put in the right side of the records form. In the following phase, the domains were identified, the covered terms that grouped many of the smaller categories. Finally, the semantic relationship was identified. Only mixed and analytical domains were found(17).

Eight cultural domains, five semantic relationships and one taxonomic analysis were found, from which six are presented because they help to describe the system of meanings attributed by the participants to the shift change reports: Expressions used by nurses to define the nurse-to-nurse shift change report; Reasons manifested by nurses to perform the shift change report; Steps 
followed during the shift change report; Place where it is performed; Forms to express the representation of selfcare hygiene; Communication strategies used by nurses during the shift change report.

\section{Results and Discussion}

Of the 33 study participants, $51.5 \%$ were in the medical group and $48.5 \%$ in the surgical group, with an average age of 35.9 years, 10.6 years of professional experience, 9.2 years working in the hospital and 3.4 years in their current service. The medical service was the first workplace for $51.5 \%$ and the surgical service was the first workplace for $15.2 \%$. Two nurses had a nursing specialization and four were attending a nursing specialization program.

Among the expressions used by nurses to define the shift change report, the following are highlighted: significant time at the beginning and at the end of shift, [...] a crucial moment for nurses to initiate and end a shift [...] (Interview 2); as a care management process, [...] it's a meeting in which care activities are updated [...] and several times a day [...] it makes the link between care and the nurses' work [...] it is a magical moment. I feel relieved afterwards, at the end of the shift it feels like I've accomplished a mission, and I feel secure and included at the beginning of it [...] (Interview 6), [...] and it allows you to resume the work already initiated by others [...] (Interview 15); it builds values, [...] it's our moment and it's sacred for nursing [...] (Interview 1); as a moment of informal education, [...] more than anything, it's an educational moment, even if you don't realize it, it's continuous and persistent, makes us keep updated and there's always something different, a test to get prepared for [...] (Interview 15).

This domain suggests the representation that the nurses hold concerning the nurse-to-nurse shift change report, which is seen as an inherited but essential activity in the current organizational context of their practice. There is an agreement among nurses concerning the maintenance of such a practice. They consider it a meeting, an encounter. It is strongly justified as a strategy for learning information and to facilitate the integration of nurses into the care activities, both the service and the continuity of them. This justification indicates the second domain: reasons manifested by the nurses to perform the shift report. The reason for action is translated in the meaning of the shift report, reinforcing the representation of such a practice, which comes from the previous domain [...] What is written is not enough [...] it takes too long to consult the medical files
[...] it has always been like this in nursing, the shift report is a tradition. I always remember this, it was inherited, sometimes we make it in a hurry, but it always helps, it saves time and facilitates the shift, then each one does his/herself because everyone knows what lays ahead [...] (Interview 8). [...] There's no point changing shifts without reporting what happened to us and to the patients. It is a matter of responsibility and respect at all levels [...] (Interview 6).

The shift report seems to save time and optimize the organization of the practice, care activities and the service, compatible with a temporary, rapid and brief opportunity to learn and transmit information about patients, as well as instructions, notes and recommendations, encouraging the implementation of normative schemes. It is also considered an advantage in relation to other ways of transmitting information such as consulting written information (shared by various instruments in the patient's process and in informatics). Similar to other studies, the shift report seems to favor the integration of care activities such that it is not necessary for nurses to expend energy thinking of all the relevant matters, including how his/ her activities, the continuity of care, and procedures will unfold(2,5,18-19). Participating in this practice for nurses means saving time and explicitly and precisely updating information while implicitly using and develop informa knowledge ${ }^{(15,19-20)}$.

The need to replace nurses at the end of a period of time is clear and confers objectivity on the organization of nursing practice and work, which means the power to achieve efficacy, including the ability to accomplish objectives, the means to ensure them and to act according to them ${ }^{(21)}$. Additionally, it marks an event that gives nurses security and relief at being replaced, when they (re)produce information concerning what they know and the care delivered to patients, because these activities are a source of concern, wearing one down [...] Afterwards, I feel relived, I feel like I've accomplished a mission at the end of the shift, I feel secure [...] and integrated when I initiate a new shift [...] (Interview 6). This replacement is in accordance with what has been discussed in other studies because it seems to contribute to reassuring nurses and enabling them to achieve emotional and even organizational balance, against the objective and subjective risks inherent to nursing practice ${ }^{(18)}$. It is worth noting that these social places are complex because individuals are dealing with life, because of the importance given to it and its inherent vital cycles. The shift report is a moment of a certain ambiguity, of change and transition ${ }^{(18)}$. In this context, it contributes 
to mitigating the effects of the shift on nurses (of those who are beginning their shift and those whose shift is ending), in the face of the need to update information so as to resume care. It is a passage to improve the efficiency of nurses' activity occurring through the transmission of objective information, recreated after a written record is made at the end of each shift and also the division of work determined by the head nurse. The head nurse has to keep order within the group and in the service, ensuring the continuity of care $\mathrm{c}^{(2-3,18-19)}$. From this perspective, the deontological code consecrates that "the nurse, in relation to the right to care in health or disease, has the obligation to ensure the continuity of care, faithfully recording performed observations and interventions"(6). The verbal report emphasizes what information to observe, seeking competence, productivity and avoiding the waste of time. The fact the shift report produces informal educational processes where practical knowledge, which is oftentimes occult, is used to save time, is in agreement with what other studies have highlighted(18-19,22).

The binomials: conceptualization - practice/ knowledge - organization emerge from these two domains and lead to issues of knowledge, which nurses posit, know and perform during the shift report. In everything an opposition seems to emerge between theoretical and practical knowledge because knowledge of distinct natures contrasts with each other $(9,20)$. The shift report is revealed in this study as a practice that occurs in a specific time and place, cyclically recreated ${ }^{(2-4,19)}$, though it is subject to permanent updating, is not always explicit, but evident in the emergence of responses to situations of emergent care(15).

The steps followed by nurses in the shift change report and the ways they use it to communicate are related to questions such as: What do nurses do? How do they do it? What to they say? How do they say it and what to they mean? There is another domain co-existing with these two: the place where the shift report is performed, which is the same in the two services and is determinant in the nurse's activity and in the services: the nursing room, [...] our room [...] (Interview 5). The organization of these two spaces indicates an evident standardization but is identified and acknowledged as a place affiliated with the category of nurses ${ }^{(19)}$ and part of nursing identity. It is a place where the diversity and specificity of information is stored (place where the processes of hospitalized patients are kept) and is exchanged (place of multiprofessional interaction). It is a place that at the same time aggregates and moves information. Moreover, it produces practical knowledge, often stressful and unpredictable, strongly marked by the direct and indirect prescription of medical knowledge ${ }^{(19,23)}$. Indirect because notations and responses of other services return to this place given the need for collaboration among services in the face of patients' needs and clinical situations.

This is a position already described in other studies and that emphasizes the existence of an elementary contradiction between the valorization of the psychosocial role of nursing as a strong aspect of the profession and its social statute determined by the objective position that the nurse occupies in care delivery ${ }^{(19,23)}$.

Preparing for this act is in line with the organization of the space and formality of the event ${ }^{(14)}$, the shift change report, given the mobilization of skills to provide objective information and to implicitly assume responsibility for performing intervenient actions. From this perspective, this ritual of the shift change report obeys strict rules, because a mistake can compromise the quality of work, the recovery and even the lives of patients(2). The sequence of steps in the shift change report basically combines the mobilization of instruments related to written information and a listening attitude. From the authorization of one to ask questions, whether by the part of the receptor, [...] how much hemoglobin was there today? Is it to prepare blood? [...] (Observation $12)$, or by the transmitter [...] who is going to take care of this patient? Is it you, J.? (Observation 12), objective and precise information is reinforced and redirected, maximizing operative reasoning. It is noteworthy that no reinforcement or request inherent to hygiene selfcare actions was recorded.

From what was observed, we can infer that the shift report emerges as a link to ensure the continuity of nursing care and to reinforce the responsibility of each nurse in care delivery decision making ${ }^{(1-4,6)}$.

The ways nurses communicate during the shift report help to identify the place they occupy in self-care concerning care delivered to inpatients, in relation to what information to hold back and what to (re)produce during the shift report. Different elements oppose the practices found: reading of records and verbal reporting. Priority is explicitly given to hygiene care in the written records, in accordance with the written sequence, after the initial verbal presentation of the identification of the patient, [...] Sir. A., bed 64. Hygiene and comfort care was delivered. He was massaged and positioned. He got out of bed at 12:30pm [...] (Observation 2); [... D. B, bed 31, hygiene care was delivered in bed, diapers were changed, the patient was positioned [...] (Observation 12); D.O, bed 34, already had a shower, has ECHO at 10 [...] (Observation 3). 
In the verbal report however these care activities come after the patient's identification, pathological situation and some general aspects (e.g. the patient's well being or conscious state) but implicitly, subjacent or attached to other situations of reported care: [...] Sir. O., bed 64, hemorrhagic stroke, 12 glasgow, no seizures, dependent on self-care (Observation 3); [...] A D. M.A., bed 51, fever plus trombocitopenia, bedridden, disoriented, with high safety bed rails [...] " (Observation 10); [...] J. F. bed 57, $H D A$, chronic alcoholic liver disease, conscious, dependent, was positioned [...]" (Observation12). Such information guides nurses to mobilize knowledge such as practical knowledge in order to identify the appropriate response and assistance required by the care situation. This knowledge originates from concrete work, knowledge that is often informal, hidden, used to maximize work or even certain practices ${ }^{(19)}$. The context functions as a space to mediate the construction of skills, thus, built knowledge is rebuilt and recomposed in the context of practice, giving origin to a new cycle of learning ${ }^{(15)}$.

Given both forms of communication used during the shift change report, through explicit or implicit verbalization of hygiene care, one can state these are present in the reported information, which is basically focused on the results of nursing interventions. Care apparently so simple, which for many nurses requires only common sense, obeys a sequence of procedures ${ }^{(19)}$, indicates continuity, connection, coherence and group cohesion $^{(24)}$, which is nevertheless close to basic nursing theory and implies the importance given to nursing foundations, hygiene, bathing and comfort.

The written records reveal that hygiene care is contained in the first notes indicating its concrete visibility, compatible with academic knowledge and knowledge originating in practice, which is often informal(2,19-20). This feature in the nurses' records and reports reinforce the fact that such care is included in a set of activities that deal with basic human needs and improves the condition of patients, according to a study that describes bathing as a therapeutic ritual(24). Hygiene care is frequent in the verbal reports in shift changes for each 24 hours, the shift change from morning to afternoon, as opposed to other shift changes, in which such information is often less frequent. This fact seems to be in accordance with the volume of activities developed in the morning shift, when patient is addressed, which helps one to perceive the characteristics of the shifts and their respective care activities $^{(18,24)}$. Information concerning hygiene care in the shift change from morning to afternoon suggests it mediates the continuity of care given the nature and sequence of activities that characterize the rhythm of the shift and even that of the other shifts. Another study addressing the subject states that the shift report is a privileged opportunity for ergonomically analyzing the work's cognitive requirements, essentially to understand how nurses regulate their activities of information management to meet work demands(3).

The ways used in the shift report to express the representation of hygiene self-care allows us to perceive its meaning for the continuity and organization of care delivered to patients and the development of nurses' skills. The interviewed nurses report these care activities are considered basic and essential to adapting the ways used for intervening in patients' situations. The need and obligation to integrate these care activities in the shift report is acknowledged though the nurses also acknowledge these are poorly addressed verbally when compared to written records; nurses consider them a requirement and a defense. In practice, the transmission of such information does not accompany the acknowledgement of the need for theoretical visibility. Routine actions that follow ritualistic performance incorporated in the hospital culture as habitual, learned and adapted practice predominate ${ }^{(25)}$. Hygiene care emerges in the shift report as a language that self-guides and helps to define many other care activities and can contribute as a way to prepare the care environment and to meet the patients' needs ${ }^{(14)}$. It is an emergent theme given its explicit and implicit presence and visibility in the shift change report. Information concerning hygiene care provided in the report at the end of the morning shift represents a privileged vehicle in terms of the objectivity of the (re)production of such information and its mediation for the care activities to follow and is a necessary element in the professional repertory of nurses ${ }^{(24)}$

\section{Conclusions}

Based on the results obtained and the literature review, this study permitted addressing the visibility of care provided in hygiene self-care in the shift change report, which contributed to comprehending the role of this information in guiding and organizing hygiene care.

The representations of the nurse-to-nurse shift change report and the characteristics that support it in these services were uncovered. The shift change report is revealed as an activity that represents the daily practice of nurses as an organizational element and part of their professional identity, marked by the difference 
it makes in health care. It is cyclically recreated in the daily work of nurses and is a mark of their professional routine. The nurse-to-nurse shift change report signals the beginning of one shift and the end of another; it is a passage configured in a space demanded by the group and occupies a determined time, however it is close to the legislated requirements. This reproduced practice indicates there is a sense of coherence in the nursing group in the updating of information and the continuity of care and serves to keep these professionals united. It reveals the expression of professional cooperation, assuming a supreme representation shared by individuals.

It highlights the visibility of hygiene care that is present in the information reported in the shift change report with a more objective and precise link in the shift change from morning to afternoon and more implicitly in the remaining shifts. Its theoretical visibility and importance is acknowledged. The acknowledged theoretical importance of this care to be presented in the shift change report is not equivalent to the importance actually given to it in practice. From the discourse and words used to express hygiene care during the shift change report, implicitly or explicitly, guidance emerges that determines what type of help is appropriate to the hygiene care activities, the many other care activities and the rhythm of the following shift. Information concerning hygiene care enables a nurse to access many of the patients' needs and to organize the ways such needs will be met, calling to itself the role of aesthetical mediation in the continuity of care, with systemic effect.

The study's results indicate that further research is needed to deepen understanding of the subject and revisit possibilities for further developing a criticalreflective foundation concerning information on hygiene self-care provided in the nurse-to-nurse shift change report.

\section{References}

1. Pimentel ILC, Siqueira PK. Passagem de Plantão: falando de paradigmas e estratégias. Acta Paul Enferm. 2005;18(4):445-50.

2. Soares CSC. A Reunião de passagem de turno: Contributos para uma Reflexão. Rev Invest Enferm. 2004 fevereiro; (9):14-23.

3. Pinho D L M, Abrahão JI, Ferreira MC. The operatory strategies and information process o the nursing work in hospital context. Rev. Latino-Am. Enfermagem. 2003;11(2):168-76.
4. Silva EE, Campos LF. Passagem de Plantão na Enfermagem: Revisão da Literatura. Cogitare enferm. 2007;12(4):502-7

5. Bártolo E. Unidade de Cuidados Intensivos Pediátricos: Um lugar onde os profissionais de saúde aprendem. Rev. cienc. educ. 2005;(5):7-18

6. Ordem dos Enfermeiros (PT). Código Deontológico do Enfermeiro: dos comentários à análise de casos. Lisboa: Ordem dos Enfermeiros; 2005.

7. Orem D. Modelo de Orem: Conceptos de enfermería en la prática. Barcelona: Ed. Científicas y Técnicas; 1993

8. Cavanagh SJ. Modelo de Orem: Aplicación Práctica. Barcelona: Masson-Salvat Enfermería; 1993.

9. Caetano JA, Pagliuca LMF. Self-care and HIV/aids patients: nursing care systematization. Rev. Latino-Am. Enfermagem. 2006;14(3):336-45.

10. International Council of Nurses - ICN: International Classification for Nursing Practice. Version 1.Geneve: ICN; 2005

11. Pokorski S, Moraes MA, Chiarelli R, Costanzi AP, Rabelo ER. Nursing process: from literature to practice. What are actually doing? Rev. Latino-Am. Enfermagem. 2009;17(3):302-7

12. Ledesma-Delgado ME, Mendes MMR. The nursing process presented as routine care actions: building its meaning in clinical nurses ' perspective. Rev. Latino-Am. Enfermagem. 17(3):328-44.

13. Araújo IMA, Silva RM, Bonfim IM, Fernan, AFC. Nursing communication in nursing care to mastectomized women: a grounded theory. Rev. LatinoAm. Enfermagem. 2010;18(1):54-60

14. Matumoto S, Mishima SM, Fortuna CM, Pereira MJB, Almeida MCP. Preparing the care relationship: a Welcoming tool in health units. Rev. Latino-Am. Enfermagem.2009;17(6):1001-8

15. Pain A. Education informelle: les effects formateurs dans le quotidian. Paris : L'Harmattan; 1990.

16. Holloway I, Wheeler S. Qualitative Research for Nurses. Oxford: Blackwell Science; 1996.

17. Spradley JP. Participant Observation. New York: Holt Rinehart and Winston; 1980.

18. Mercadier C. O trabalho emocional dos prestadores e cuidados em meio hospitalar: O corpo, âmago da interacção prestador de cuidados - doente. Loures: Lusociência; 2004.

19. Guimarães P. Espaço, tempo e processos de educação informal numa enfermaria. Rev Educ. 2002;15(1):85-109. 
20. Barbier JM. Savoirs Théoriques et Savoirs d'Action.

Paris: PUF; 1996.

21- Hawks JH. Power: a concept analysis. J Adv Nurs. 1991;16(6):754-62.

22. Atkinson LD, Murray ME. Fundamentos de enfermagem. Rio de Janeiro: Guanabara Koogan; 1989.

23. Carapinheiro G. Saberes e Poderes no Hospital: Uma Sociologia dos Serviços Hospitalares. Porto: Edições Afrontamento; 1993.

24. Wolf Z. Nursing rituals. Can J Nurs Res. $1988 ; 20(3): 59-69$.

25. Mantzoukas $S$, Jasper M. Reflective practice and daily ward realy: a covert power game. J Clin Nurs. 2004; 13:923-33. 